
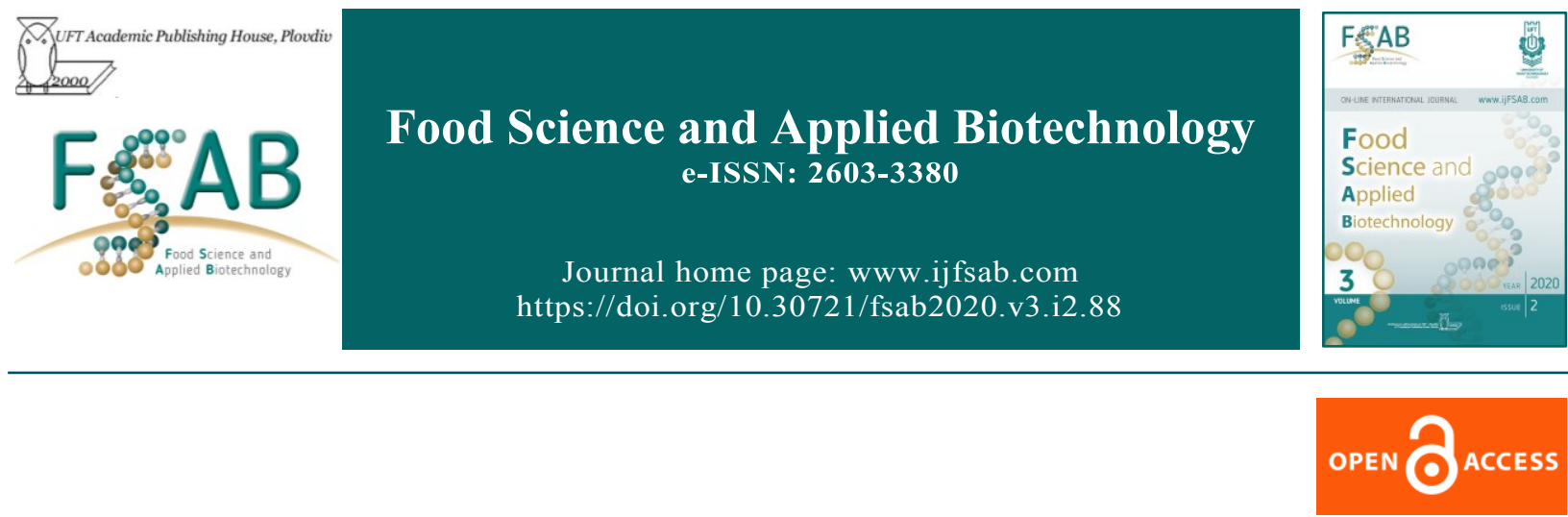

Review Article

\title{
The microbiology of Greek/Cyprus trahanas and of Turkish tarhana: A review
}

\author{
Aikaterini Georgala ${ }^{1 \square}$ \\ ${ }^{1}$ Laboratory of Dairy Research, Department of Food Science \& Human Nutrition, Agricultural University of Athens, \\ 75 Iera Odos Str., 11855, Athens, Greece
}

\begin{abstract}
Trahanas is the most known fermented milk-cereal product of Greece and Cyprus. It is produced from ewe's or goat's milk or a mixture of them during summer. For making Trahanas, wheat that is firstly broken is added to the fermented milk. The mixture is heated and cooled, cut into small pieces and dried in the sun or oven-dried. Many microorganisms were found during its fermentation. Lactic acid bacteria were the main group of microorganisms found followed by yeasts. Species such as Streptococcus lactis, Lactobacillus bulgaricus, Lactobacillus lactis etc. are known to contribute to Trahanas fermentation playing a basic role for acid and aroma formation. Concerning Turkish Tarhana, it is made by mixing cereal flour, yoghurt, baker's yeast, cooked vegetables, salt and spices that were fermented by one up to seven days and then air dried. The raw materials, the time of fermentation and the methods used for Tarhana preparation influence the lactic acid bacteria species presence which afterwards contribute to the acid and aroma formation of the final product. Many species of lactic acid bacteria such as Lactococcus lactis, Lactobacillus lactis etc. are known to contribute to Tarhana dough fermentation as well as the yeast Saccharomyces cerevisiae.
\end{abstract}

Keywords: trahanas, tarhana, microbiology

Abbreviations: APC - aerobic plate count; BMF - boiled milk preparation; CFT - chickpea flour tarhana; FWT - fresh wet tarhana; LAB - lactic acid bacteria; MAF - un-boiled milk preparation; MRS - de ManRogosa-Sharpe-Agar; NSLAB - non-starter lactic acid bacteria; TB - total bacterial (number); TH - tarhana herb; TMAB - total mesophilic aerobic bacteria; SAB - Sabouraud agar; WWFT - whole wheat flour tarhana

${ }^{\square}$ Corresponding author: Laboratory of Dairy Research, Department of Food Science \& Human Nutrition, Agricultural University of Athens, 75 Iera Odos Str., 11855, Athens, Greece, tel.: +302105296444, fax:+30.2105294672,E-mail: georgala@aua.gr

\section{Article history:}

Received 18 December 2019

Reviewed 19 February 2020

Accepted 28 February 2020

Available on-line 08 September 2020

https://doi.org/10.30721/fsab2020.v3.i2.88

Georgala, 2020

(C) 2020 The Authors. UFT Academic publishing house, Plovdiv 


\section{Introduction}

Fermented milk-cereal products are extensively used for feeding people in the Middle East and other parts of the word such as Asia, Africa and some parts of Europe. The traditional products 'Trahanas' in Greece and Cyprus and 'Tarhana' in Turkey are two fermented foods with interesting organoleptic characteristics. These products are very nutritious as a result of the nutritional characteristics of wheat and milk/yoghurt used for their production. The production methods for traditional fermented milk cereal foods are mainly based to cereals and fermented milk and differ from place to place. In Egypt, Syria, Lebanon and Jordan the fermented milk cereal product Kishk is produced while Kushuk is produced in Iraq and Tarhonya/Talkuna in Hungary and Filand (Tamime and O'Connor 1995; Daglioglu 2000; Ozdemir et al. 2007; Georgala 2012). For the production of Trahanas fresh milk (ewe's, goat's or mixture) is used which is left to acidify for some days' either spontaneously or by adding a yoghurt culture by stirring every day until the desired acidity is reached. Afterwards, wheat that is broken is added to the fermented milk usually in a ratio $3: 1$ or $4: 1$ and the mixture is heated to cook. A thick paste is made which is cooled and is cut into a finger size pieces. Then, it is dried in the sun or oven-dried. If Trahanas is well dried it is put in a cool place. Eggs could also be added during the Trahanas making process and then the trahanas is named 'sour Trahanas with eggs'. Also, instead of acidified milk, fresh milk that is not left to sour can be used for Trahanas preparation and then the final product is named 'Sweet Trahanas'. Sometimes for the production of Trahanas the milk is replaced by a pulp of vegetables and then the final product is named 'Nistisimos Trahanas'. Generally, Trahanas is a very nutritious food (source of proteins, minerals etc.) and it is extensively used for feeding people and elderly people (Economidou and Steinkraus 1983; Bozoudi et al. 2017). Tarhana food (the dry form of a yoghurt/cereal mixture) is the oldest and most known fermented product of Turkey which is widely used for feeding Turkish people and it is an important part of their diet. Tarhana is produced in different Turkish areas with methods that vary from place to place. Tarhana is used for soup making but alternatively can be used as a snack after being dried to a thin layer or nugget but not grounded. Tarhana has a sour/acidic taste and a yeasty flavour. It is produced by mixing cereal flour (mainly wheat flour), yoghurt, baker's yeast (Saccharomyces cerevisiae), various vegetables (tomatoes, onions, green and red peppers), salt, spices (mint, thyme, dill, tarhana herb etc.) and is fermented for one to seven days. Afterwards, it is air dried and used for making a soup. Tarhana is a high nutritious food (a very good source of proteins, vitamins etc.) and healthy for medical patients, children and elderly people (Daglioglu 2000; Ozdemir et al. 2007). This work discusses and review the microbiology characteristics of the two fermented milk/cereal foods 'Greek/Cyprus Trahanas' and 'Turkish Tarhana'.

Microbiological characteristics of 'Greek Trahanas' and 'Cyprus Trahanas'. Lazos et al. (1993) studied microbiology of Greek Trahanas that was made from boiled or un-boiled milk. The milks (boiled or un-boiled) were fermented for $35 \mathrm{~h}$ for curd separation. Then the mixtures were fermented for $15 \mathrm{~h}$. In un-boiled milk preparation (MAF) the maximum value of Streptococcus microorganisms was observed after $23 \mathrm{~h}$ fermentation. However, their growth limited after the $30 \mathrm{~h}$ as $\mathrm{pH}$ failed to 4.36 and acidity value was $0.82 \%$ lactic acid. In boiled milk preparation (BMF) Streptococcus microorganisms showed their maximum value after $30 \mathrm{~h}$ and reduced thereafter as $\mathrm{pH}$ dropped to 4.42 and acidity was $0.72 \%$ lactic acid. Generally, the total count of microorganisms and Lactobacillus species were found to steadily increase as fermentation time goes on. However, streptococci grow up to $23 \mathrm{~h}$ of fermentation and low down afterwards as $\mathrm{pH}$ dropped to value $<5.0-4.5$. Similar trend showed coliforms. Coliforms were generally found in lower numbers. Also, a low yeasts and moulds population was found which was stable during the fermentation process. Yeasts and moulds counts increased in enough lactic acid (0.4 $0.7 \%$ ) concentration. In MAF preparation the main microorganisms were $S$. lactis and $S$. diacetylactis. However, S. cremoris was found in low numbers. At the beginning of Trahanas fermentation, Lactobacillus casei and Lactobacillus lactis species predominated while later on cultures of Lactobacillus acidophilus and Lactobacillus bulgaricus were isolated. By the increase of $L$. bulgaricus counts, a decrease of $L$. acidophilus 
counts was observed. Streptococcus faecalis, Leuconostoc cremoris and Lactobacillus acidophilus species were not found in the MBF preparation. L. casei and L. bulgaricus were the only lactobacilli found. From cocci, $S$. lactis and $S$. diacetylactis were the main microorganisms determined. Streptococcus diacetylactis and Leuconostoc cremoris were found to be the main aroma producing microorganisms while Streptococcus lactis, Lactobacillus casei and Lactobacillus bulgaricus the main acid producing ones. It was shown that a $50 \mathrm{~h}$ lactic acid fermentation takes place in Greek Trahanas food. Also, the above mentioned microorganisms contribute mainly to the acid and aroma formation (Table 1). Bozoudi et al. (2017) examined the Cyprus Trahanas microbiological characteristics. This work studied the autochthonous microbiota of Cyprus Trahanas and a great biodiversity of the authentic microbiota was observed. The main group of microorganisms were the lactic acid bacteria (LAB) followed by the yeasts.

Table 1. Changes in microbial flora during Greek trahanas fermentation (Reference: Lazos et al. 1993)

\begin{tabular}{lccccccc}
\hline $\begin{array}{l}\text { Trahanas MAF } \\
\text { preparation } \\
\text { Microorganisms }\end{array}$ & 0 & 5 & 10 & 15 & 23 & 30 & 35 \\
\hline Total count & $3 \times 10^{5}$ & $31 \times 10^{5}$ & $65 \times 10^{6}$ & $18 \times 10^{7}$ & $10 \times 10^{8}$ & $23 \times 10^{9}$ & $47 \times 10^{9}$ \\
S. faecalis & $24.3 \times 10^{3}$ & $16 \times 10^{4}$ & $23.5 \times 10^{5}$ & $72 \times 10^{5}$ & $34.0 \times 10^{5}$ & $5 \times 10^{3}$ & - \\
$S$. lactis & $96.0 \times 10^{3}$ & $42.0 \times 10^{4}$ & $10.4 \times 10^{6}$ & $63.2 \times 10^{6}$ & $30.6 \times 10^{7}$ & $44.2 \times 10^{6}$ & $47.5 \times 10^{5}$ \\
S. diacetylactis & $22.7 \times 10^{3}$ & $17.3 \times 10^{4}$ & $12.4 \times 10^{5}$ & $76.8 \times 10^{5}$ & $81.2 \times 10^{6}$ & $38.4 \times 10^{5}$ & $25.0 \times 10^{4}$ \\
S. cremoris & $19.5 \times 10^{2}$ & $12.0 \times 10^{3}$ & $32.5 \times 10^{5}$ & $63.0 \times 10^{5}$ & $35.0 \times 10^{4}$ & $18.0 \times 10^{4}$ & $11.2 \times 10^{3}$ \\
L. cremoris & $13.0 \times 10^{3}$ & $14.5 \times 10^{4}$ & $10.9 \times 10^{5}$ & $91.6 \times 10^{5}$ & - & - & - \\
L. lactis & $1.0 \times 10^{4}$ & $11.0 \times 10^{4}$ & $4.0 \times 10^{6}$ & $17.6 \times 10^{6}$ & $12.2 \times 10^{7}$ & $29.5 \times 10^{8}$ & $28.2 \times 10^{8}$ \\
L. casei & $12.8 \times 10^{4}$ & $99.0 \times 10^{4}$ & $36.0 \times 10^{6}$ & $72.9 \times 10^{6}$ & $48.8 \times 10^{7}$ & $14.8 \times 10^{9}$ & $37.6 \times 10^{9}$ \\
L. bulgaricus & - & - & - & - & $82.0 \times 10^{5}$ & $98.5 \times 10^{6}$ & $47.0 \times 10^{8}$ \\
L. acidophilus & - & - & - & $15.0 \times 10^{5}$ & $35.0 \times 10^{5}$ & $19.7 \times 10^{6}$ & $18.8 \times 10^{7}$ \\
\hline Trahanas MBF & & & & & & & \\
$\quad$ preparation & & & & & & & \\
Microorganisms & 0 & 5 & 10 & 15 & 23 & 30 & 35 \\
\hline Total count & $3.8 \times 10^{2}$ & $15 \times 10^{3}$ & $1 \times 10^{4}$ & $1 \times 10^{5}$ & $16 \times 10^{8}$ & $45 \times 10^{9}$ & $22 \times 10^{10}$ \\
S. lactis & - & $9.2 \times 10^{2}$ & $3.0 \times 10^{3}$ & $6.3 \times 10^{4}$ & $5.3 \times 10^{8}$ & $18.8 \times 10^{9}$ & $14.0 \times 10^{6}$ \\
S. diacetylactis & - & - & - & - & $4.2 \times 10^{8}$ & $2.7 \times 10^{7}$ & $1.0 \times 10^{6}$ \\
L. casei & - & $5.8 \times 10^{2}$ & $3.6 \times 10^{3}$ & $3.0 \times 10^{5}$ & $6.0 \times 10^{8}$ & $27.1 \times 10^{9}$ & $16.8 \times 10^{10}$ \\
L. bulgaricus & - & - & $1.2 \times 0^{3}$ & $4.0 \times 10^{4}$ & $8.5 \times 10^{7}$ & $9.2 \times 10^{9}$ & $4.5 \times 10^{10}$ \\
\hline
\end{tabular}

From raw milk used in Tarhana production the microbial species of Lactococcus, Lactobacillus and Enterococcus were frequently isolated. However, Lactobacillus casei/paracasei was the main microorganism found in the starter culture. Lactococci, lactobacilli and yeasts were the main species found during a $5 \mathrm{~d}$ fermentation. At the beginning of Trahanas fermentation $27.9 \%$ of isolates were Lactococcus lactis and Lactococcus $s p p$. in their higher numbers were found on the 3rd day of fermentation (Table 2). However, as a result of the acidic condition $(\mathrm{pH} 3.8)$ of the fermented milk and the cell lysis, no Lactococcus species were detected at the 5th $\mathrm{d}$ of fermentation (end). Although Lactobacillus species were found in low counts at the first two days of fermentation they were highly increased (20\% of isolates) at the 5 th day (end of fermentation) (Table 2). Saccharomyces unisporus was the predominant yeast throughout the whole fermentation period $(17.9 \%$ of the isolates at the end of fermentation). Also, Lactobacillus spp. predominated during the fermentation process (Table 2). The higher counts of LAB on MRS agar ( $\mathrm{pH}$ 6.2) and LAB on M-17 agar were found at the 
4th d fermentation (Table 2) while the total aerobic counts and the LAB on MRS agar ( $\mathrm{pH}$ 5.7) reached their higher numbers on the 3rd day of fermentation (Table 2). However, a significant decrease in the number of the above microorganisms was found at the end of fermentation (Table 2) as a result of the acidic environment ( $\mathrm{pH}$ falling) that NSLAB cause. The LAB on M-17 agar population and the yeasts numbers were found in high levels throughout the whole fermentation time (Table 2). The results of this study showed a great biodiversity of microorganisms in the traditional Cyprus Trahanas (in respect with microorganisms found in milk), with Lactococcus, Lactobacillus and yeast species to contribute mainly to the completion of fermentation.

Microbiological characteristics of 'Turkish Tarhana'. Ibanoglu et al. (1999) examined the influence of different materials on Tarhana fermentation. Three Tarhana samples were made: a) Standard Tarhana (sample S1) with yoghurt to wheat flour ratio: 0.5 and $80.0 \mathrm{~g}$ salt $/ \mathrm{kg}$ wheat flour added, b) Sample S2 with yoghurt to wheat flour ratio: 1.0 and $80.0 \mathrm{~g}$ salt $/ \mathrm{kg}$ wheat flour added and c) Sample S3 with yoghurt to wheat flour ratio: 0.5 but without salt added. In sample S2 the total bacterial (TB) number and the lactic acid bacteria (LAB) count were higher than that found in the rest examined samples as more yogurt was added to this sample (Table 3a). The microbial changes during Tarhana fermentation are shown in Table 3a. The total bacteria and the lactic acid bacteria numbers varied before fermentation as different preparations of Tarhana were made (Table 3a). As it was expected, the total and lactic acid bacteria count of Tarhana with increased yoghurt content (sample S2) were higher as compared to the rest examined samples as more yoghurt was added to this sample. In all Tarhana samples, the groups of microorganisms were significantly increased during the day one of fermentation. Afterwards, the microbial populations were gradually decreased (Table 3a). This resulted to lower microbial counts at the end of fermentation as compared to their initial numbers (Table 3a). At the end of fermentation, the lactic acid bacteria were found in higher numbers in Sample S3 than in the rest one samples (Table 3a). By adding salt before fermentation a lower fermentation activity was observed and a lower lactic acid content was found. Erbas et al. (2005) studied the microbiological characteristics of wet and dry Tarhana during a 6 month storage period (Table 4e). The microbiological changes of Tarhana dough during fermentation were also studied (Table $4 \mathrm{e})$. The Tarhana dough was fermented at $25^{\circ} \mathrm{C}$ for $3 \mathrm{~d}$ in an incubator and it was kneaded daily in order to help the fermentation process. For the examination of microbial changes through fermentation, samples were taken at $0,1 \mathrm{st}, 2 \mathrm{nd}$ and $3 \mathrm{rd} \mathrm{d}$ of fermentation. At the beginning of Tarhana fermentation the counts of total mesophilic aerobic bacteria (TMAB), LAB (Lactobacillus spp.) and yeast and moulds were approximately the same (Table 4e). TMAB and LAB increased on the first day of fermentation (Table 4e). However, the next days, the content of these microorganisms decreased as a result of the increased acid content. The LAB (Lactobacillus spp.) count dropped from $6.47 \log 10$ $\mathrm{cfu} / \mathrm{g}$ on day 0 to $5.44 \log 10 \mathrm{cfu} / \mathrm{g}$ on day 3 (end) of fermentation. TMAB count decreased from 6.43 $\log 10 \mathrm{cfu} / \mathrm{g}$ on day 0 to $5.95 \log 10 \mathrm{cfu} / \mathrm{g}$ on day 3 (end) of fermentation (Table 4e). Also, yeasts and moulds counts steadily decreased during the fermentation process (Table 4e). No coliforms were found in any of the tested Tarhana samples during the whole fermentation and storage time (Table 4e). This showed no environmental or raw material contamination. At the end of fermentation, the fresh wet Tarhana (FWT) was separated into five parts. The first part of dough as being $(\mathrm{N})$, the second part with sodium benzoate $(1000 \mathrm{mg} / \mathrm{g})$ named (A) and the third part with $6.5 \mathrm{~g} / 100 \mathrm{~g}$ salt on, named (S), were stored for 6 months at room temperature. However, the fourth part of dough named $\mathrm{F}$ was put at $4^{\circ} \mathrm{C}$. Finally, the fifth part of dough named $\mathrm{C}$ was sun dried, grounded and stored. This was used as a control sample. Before their storage the samples were put in small jars and hermetically closed. Samples were taken for analysis at the $0,1 \mathrm{st}, 2 \mathrm{nd}$, $3 \mathrm{rd}$, 4th, 5th and 6th months of their storage. The storage type of Tarhana as well as the storage time were found to significantly affect the TMAB, LAB, yeast and moulds counts (Table $4 \mathrm{e}$ ). The counts of $\mathrm{TMAB}, \mathrm{LAB}$, yeast and moulds were found to continuously decrease through the storage period (Table 4e) as temperature, acid content, osmotic 
Table 2. Populations $\left(\log _{10} \mathrm{cfu} / \mathrm{ml}\right)$ of lactic acid bacteria (LAB), yeasts, total aerobic counts and isolated microbial strains during Cypriot Trahanas fermentation (Reference: Bozoudi et al. 2017)

\begin{tabular}{|c|c|c|c|c|c|c|c|}
\hline \multirow{2}{*}{$\begin{array}{l}\text { Cypriot Trahanas } \\
\text { (Fermented milk) } \\
\text { Group of } \\
\text { microorganisms }\end{array}$} & \multicolumn{5}{|c|}{ Fermentation time, $d$} & & \\
\hline & Day 1 & Day 2 & Day 3 & Day 4 & Day 5 & & \\
\hline $\begin{array}{l}\text { LAB on MRS agar, } \\
\text { pH } 6.2\end{array}$ & $5.20 \pm 0.20$ & $7.30 \pm 0.98$ & $7.71 \pm 1.10$ & $7.92 \pm 0.41$ & $6.89 \pm 0.61$ & & \\
\hline $\begin{array}{l}\text { LAB on MRS agar, } \\
\text { pH } 5.7\end{array}$ & $5.13 \pm 0.16$ & $6.83 \pm 0.83$ & $7.76 \pm 0.43$ & $7.36 \pm 0.51$ & $6.97 \pm 0.40$ & & \\
\hline LAB on M17 agar & $3.82 \pm 0.49$ & $5.18 \pm 0.44$ & $5.48 \pm 0.22$ & $5.62 \pm 0.71$ & $5.49 \pm 0.27$ & & \\
\hline Yeasts & $3.23 \pm 0.69$ & $3.93 \pm 0.54$ & $4.98 \pm 0.92$ & $5.53 \pm 0.81$ & $5.54 \pm 0.67$ & & \\
\hline Total aerobic counts & $5.89 \pm 0.24$ & $7.59 \pm 1.06$ & $8.41 \pm 0.11$ & $8.14 \pm 0.19$ & $7.23 \pm 1.13$ & & \\
\hline \multicolumn{2}{|l|}{ Isolated species } & \multicolumn{3}{|c|}{ Fermentation time, $\mathrm{d}$} & & \multirow{2}{*}{$\begin{array}{c}\text { Number of } \\
\text { isolates in } \\
\text { total }\end{array}$} & \multirow{2}{*}{$\begin{array}{c}\text { Percentage } \\
\%\end{array}$} \\
\hline Lactic acid bacteria & Day 1 & Day 2 & Day 3 & Day 4 & Day 5 & & \\
\hline Lactococcus lactis & 6 & 11 & 14 & 8 & - & 39 & 27.9 \\
\hline Lactococcus sp. & - & 1 & 8 & 1 & - & 10 & 7.1 \\
\hline $\begin{array}{l}\text { Lactobacillus } \\
\text { casei/paracasei }\end{array}$ & 4 & 3 & - & - & - & 7 & 5.0 \\
\hline $\begin{array}{l}\text { Lactobacillus } \\
\text { helveticus }\end{array}$ & 1 & - & - & - & - & 1 & 0.7 \\
\hline Lactobacillus spp. & 2 & 1 & - & - & 25 & 28 & 20.0 \\
\hline $\begin{array}{l}\text { Enterococcus } \\
\text { faecalis }\end{array}$ & 1 & 1 & 2 & 3 & 1 & 8 & 5.7 \\
\hline $\begin{array}{l}\text { Enterococcus } \\
\text { faecium }\end{array}$ & - & - & - & - & 1 & 1 & 0.7 \\
\hline $\begin{array}{l}\text { Enterococcus } \\
\text { canintestini }\end{array}$ & - & - & - & - & 1 & 1 & 0.7 \\
\hline Enterococcus spp. & - & 1 & 1 & 1 & - & 3 & 2.1 \\
\hline $\begin{array}{l}\text { Leuconostoc } \\
\text { mesenteroides } \\
\text { Other bacteria }\end{array}$ & - & - & - & 1 & - & 1 & 0.7 \\
\hline $\begin{array}{l}\text { Staphylococcus } \\
\text { epideridis }\end{array}$ & 1 & - & - & - & - & 1 & 0.7 \\
\hline Enterobacter spp. & - & - & - & - & 1 & 1 & 0.7 \\
\hline Acinetobacter spp. & - & 1 & - & - & - & 1 & 0.7 \\
\hline $\begin{array}{l}\text { Acetobacter } \\
\text { cibinongensis } \\
\text { Yeasts }\end{array}$ & - & - & - & - & 1 & 1 & 0.7 \\
\hline $\begin{array}{l}\text { Saccharomyces } \\
\text { unisporus }\end{array}$ & 6 & 2 & 3 & 6 & 8 & 25 & 17.9 \\
\hline Saccharomyces spp. & - & - & 3 & 1 & - & 4 & 2.9 \\
\hline $\begin{array}{l}\text { Kluyveromyces } \\
\text { marxianus }\end{array}$ & 3 & 2 & 1 & 2 & - & 8 & 5.7 \\
\hline Total & 24 & 23 & 32 & 23 & 38 & 140 & 100.00 \\
\hline
\end{tabular}


Table 3a. Microbial changes during Tarhana fermentation (References: Ibanoglu et al. 1999)

\begin{tabular}{|c|c|c|c|c|c|}
\hline \multirow{2}{*}{$\begin{array}{l}\text { Tarhana samples } \\
\text { S1 (standard tarhana) } \\
\text { Group of microorganisms, } \\
\text { cfu/g dry matter }\end{array}$} & \multicolumn{5}{|c|}{ Fermentation time, $d$} \\
\hline & Day 0 & Day 1 & Day 2 & Day 3 & Day 4 \\
\hline TB & $5.3 \times 10^{7} \pm 1 \times 10^{5}$ & $2.7 \times 10^{8} \pm 2 \times 10^{5}$ & $6.9 \times 10^{7} \pm 9 \times 10^{4}$ & $6.6 \times 10^{7} \pm 1 \times 10^{5}$ & $4.5 \times 10^{7} \pm 1 \times 10^{4}$ \\
\hline LAB & $6.6 \times 10^{7} \pm 4 \times 10^{5}$ & $9.6 \times 10^{7} \pm 3 \times 10^{5}$ & $2.7 \times 10^{7} \pm 1 \times 10^{5}$ & $4.1 \times 10^{6} \pm 3 \times 10^{4}$ & $4.0 \times 10^{6} \pm 2 \times 10^{4}$ \\
\hline $\mathrm{Y}$ & $8.4 \times 10^{6} \pm 3 \times 10^{4}$ & $2.8 \times 10^{7} \pm 3 \times 10^{4}$ & $9.1 \times 10^{6} \pm 3 \times 10^{4}$ & $2.3 \times 10^{6} \pm 1 \times 10^{4}$ & $2.2 \times 10^{6} \pm 1 \times 10^{4}$ \\
\hline \multicolumn{6}{|l|}{$\begin{array}{l}\text { S2 (tarhana with } \\
\text { increased yoghurt) } \\
\text { Group of microorga } \\
\text { cfu/g dry matter }\end{array}$} \\
\hline $\mathrm{TB}$ & $5.1 \times 10^{8} \pm 2 \times 10^{5}$ & $1.3 \times 10^{9} \pm 3 \times 10^{5}$ & $1.2 \times 10^{7} \pm 1 \times 10^{5}$ & $6.4 \times 10^{6} \pm 2 \times 10^{4}$ & $6.4 \times 10^{6} \pm 1 \times 10^{4}$ \\
\hline LAB & $2.0 \times 10^{8} \pm 2 \times 10^{5}$ & $1.5 \times 10^{8} \pm 3 \times 10^{5}$ & $3.7 \times 10^{7} \pm 1 \times 10^{5}$ & $1.6 \times 10^{7} \pm 1 \times 10^{5}$ & $1.5 \times 10^{7} \pm 1 \times 10^{5}$ \\
\hline $\mathrm{Y}$ & $8.6 \times 10^{6} \pm 1 \times 10^{5}$ & $2.9 \times 10^{7} \pm 4 \times 10^{5}$ & $9.2 \times 10^{6} \pm 1 \times 10^{5}$ & $2.2 \times 10^{6} \pm 1 \times 10^{4}$ & $2.2 \times 10^{6} \pm 1 \times 10^{4}$ \\
\hline \multicolumn{6}{|l|}{$\begin{array}{l}\text { Tarhana S3 (tarhana } \\
\text { without salt) } \\
\text { Group of microorganisms, } \\
\text { cfu/g dry matter }\end{array}$} \\
\hline $\mathrm{TB}$ & $5.5 \times 10^{7} \pm 1 \times 10^{5}$ & $1.4 \times 10^{8} \pm 1 \times 10^{5}$ & $8.3 \times 10^{7} \pm 1 \times 10^{5}$ & $2.3 \times 10^{7} \pm 4 \times 10^{4}$ & $1.6 \times 10^{7} \pm 1 \times 10^{5}$ \\
\hline LAB & $9.2 \times 10^{7} \pm 3 \times 10^{5}$ & $4.4 \times 10^{8} \pm 3 \times 10^{5}$ & $6.8 \times 10^{8} \pm 5 \times 10^{5}$ & $6.9 \times 10^{7} \pm 2 \times 10^{4}$ & $3.8 \times 10^{7} \pm 2 \times 10^{5}$ \\
\hline $\mathrm{Y}$ & $8.5 \times 10^{6} \pm 4 \times 10^{5}$ & $2.8 \times 10^{7} \pm 1 \times 10^{5}$ & $9.3 \times 10^{6} \pm 1 \times 10^{5}$ & $2.4 \times 10^{6} \pm 8 \times 10^{4}$ & $2.3 \times 10^{6} \pm 1 \times 10^{5}$ \\
\hline
\end{tabular}

TB: Total bacterial count, LAB: Lactic acid bacteria, Y: Yeast

Table 3b. Microbial changes during Tarhana fermentation (References: Settanni et al. 2011)

\begin{tabular}{|c|c|c|c|c|c|}
\hline \multirow{2}{*}{$\begin{array}{l}\text { Tarhana } \\
\text { Dough A (incubated at } 30^{\circ} \mathrm{C} \text { ) } \\
\text { Group of microorganisms, } \\
\text { cfu/g culture media }\end{array}$} & \multicolumn{4}{|c|}{ Fermentation time, $d$} & \multirow[b]{2}{*}{ Day 8} \\
\hline & Day 0 & Day 2 & Day 4 & Day 6 & \\
\hline Total mesophilic counts/PCA agar & $7.50 \pm 0.3$ & $8.0 \pm 0.6$ & $8.4 \pm 0.4$ & $7.3 \pm 0.4$ & $6.9 \pm 0.0$ \\
\hline Coliforms /VRBA agar & 0 & 0 & 0 & 0 & 0 \\
\hline LAB-Mesophilic rods/MRS agar $30^{\circ} \mathrm{C}$ & $7.4 \pm 0.2$ & $8.0 \pm 0.3$ & $8.4 \pm 0.5$ & $7.6 \pm 0.5$ & $7.2 \pm 0.7$ \\
\hline LAB-Mesophilic cocci/M-17 agar $30^{\circ} \mathrm{C}$ & $7.7 \pm 0.3$ & $8.1 \pm 0.6$ & $8.2 \pm 0.3$ & $7.6 \pm 0.4$ & $7.0 \pm 0.4$ \\
\hline LAB-Thermophilic rods/MRS agar $40^{\circ} \mathrm{C}$ & $6.7 \pm 0.3$ & $7.9 \pm 0.6$ & $8.2 \pm 0.0$ & $7.8 \pm 0.4$ & $7.4 \pm 0.1$ \\
\hline LAB-Mesophilic rods/M-17 agar $40^{\circ} \mathrm{C}$ & $7.9 \pm 0.3$ & $8.0 \pm 0.2$ & $8.1 \pm 0.3$ & $7.5 \pm 0.6$ & $7.2 \pm 0.0$ \\
\hline Total yeasts/PDA agar & $7.2 \pm 0.3$ & $8.0 \pm 0.2$ & $8.0 \pm 0.2$ & $7.5 \pm 0.2$ & $7.3 \pm 0.5$ \\
\hline Non-Saccharomyces yeasts/LA agar & $3.3 \pm 0.3$ & $2.3 \pm 0.3$ & $3.1 \pm 0.4$ & $4.0 \pm 0.5$ & $2.5 \pm 0.0$ \\
\hline $\begin{array}{l}\text { Dough B } \\
\text { (incubated at } 40^{\circ} \mathrm{C} \text { ) }\end{array}$ & Day 0 & Day 2 & Day 4 & Day 6 & Day 8 \\
\hline Total mesophilic counts/PCA agar & $7.5 \pm 0.3$ & $7.6 \pm 0.3$ & $8.3 \pm 0.4$ & $7.8 \pm 0.1$ & $7.3 \pm 0.1$ \\
\hline Coliforms/VRBA agar & 0 & 0 & 0 & 0 & 0 \\
\hline LAB-Mesophilic rods/MRS agar $30^{\circ} \mathrm{C}$ & $7.4 \pm 0.7$ & $7.4 \pm 0.3$ & $8.2 \pm 0.3$ & $7.8 \pm 0.2$ & $7.9 \pm 0.6$ \\
\hline LAB-Mesophilic cocci/M-17 agar $30^{\circ} \mathrm{C}$ & $7.7 \pm 0.3$ & $7.2 \pm 0.2$ & $8.2 \pm 0.3$ & $7.8 \pm 0.7$ & $7.9 \pm 0.3$ \\
\hline LAB-Thermophilic rods/MRS agar $40^{\circ} \mathrm{C}$ & $6.7 \pm 0.3$ & $7.0 \pm 0.6$ & $8.3 \pm 0.7$ & $7.8 \pm 0.7$ & $7.9 \pm 0.4$ \\
\hline LAB-Mesophilic rods/M-17 agar $40^{\circ} \mathrm{C}$ & $7.9 \pm 0.5$ & $7.1 \pm 0.0$ & $7.9 \pm 0.3$ & $7.9 \pm 0.3$ & $7.8 \pm 0.7$ \\
\hline Total yeasts/PDA agar & $7.2 \pm 0.5$ & $7.5 \pm 0.4$ & $8.3 \pm 0.3$ & $7.9 \pm 0.4$ & $7.8 \pm 0.6$ \\
\hline Non-Saccharomyces yeasts/LA agar & $3.3 \pm 0.6$ & $3.0 \pm 0.0$ & $2.6 \pm 0.6$ & $3.9 \pm 0.4$ & $2.1 \pm 0.4$ \\
\hline
\end{tabular}

$\mathrm{T}_{0}$ : zero time, d: days 
Table 3c. Microbial changes during Tarhana fermentation (References: Demirci et al. 2018)

\begin{tabular}{|c|c|c|c|c|c|}
\hline \multirow{2}{*}{$\begin{array}{l}\text { Tarhna samples } \\
\text { Tarhana sample A } \\
\text { Microorganisms, } \log _{10} \mathrm{cfu} / \mathrm{g}\end{array}$} & \multicolumn{5}{|c|}{ Fermentation time, $d$} \\
\hline & Day 0 & Day 1 & Day 3 & Day 5 & Day 7 \\
\hline TMAB & $7.30 \pm 0.01$ & $8.0 \pm 0.20$ & $7.99 \pm 0.02$ & $7.81 \pm 0.01$ & $7.9 \pm 0.1$ \\
\hline Yeast and Mould & $7.45 \pm 0.02$ & $8.4 \pm 0.3$ & $7.9 \pm 0.2$ & $7.7 \pm 0.1$ & $7.76 \pm 0.02$ \\
\hline Coliform & $2.4 \pm 0.4$ & $<2.0$ & $<2.0$ & $<2.0$ & $<2.0$ \\
\hline S. aureus & $2.6 \pm 0.2$ & $<2.0$ & $<2.0$ & $<2.0$ & $<2.0$ \\
\hline LAB (MRS) & $8.40 \pm 0.01$ & $8.00 \pm 0.08$ & $7.86 \pm 0.02$ & $7.86 \pm 0.04$ & $7.89 \pm 0.02$ \\
\hline M 17 & $8.49 \pm 0.07$ & $8.04 \pm 0.01$ & $8.0 \pm 0.1$ & $7.86 \pm 0.02$ & $7.89 \pm 0.07$ \\
\hline \multicolumn{6}{|l|}{ Tarhana sample B } \\
\hline \multicolumn{6}{|l|}{ Microorganisms, $\log _{10} \mathrm{cfu} / \mathrm{g}$} \\
\hline TMAB & $7.34 \pm 0.02$ & $7.95 \pm 0.06$ & $7.75 \pm 0.01$ & $7.71 \pm 0.08$ & $7.72 \pm 0.02$ \\
\hline Yeast and Mould & $7.32 \pm 0.03$ & $7.85 \pm 0.04$ & $7.7 \pm 0.1$ & $7.67 \pm 0.03$ & $7.7 \pm 0.2$ \\
\hline Coliform & $2.5 \pm 0.2$ & $2.0 \pm 0.3$ & $<2.0$ & $<2.0$ & $<2.0$ \\
\hline S. aureus & $4.3 \pm 0.2$ & $1.98 \pm 0.08$ & $1.69 \pm 0.05$ & $<2.0$ & $<2.0$ \\
\hline LAB (MRS) & $8.30 \pm 0.01$ & $7.95 \pm 0.03$ & $7.8 \pm 0.1$ & $7.8 \pm 0.1$ & $7.94 \pm 0.02$ \\
\hline M 17 & $8.41 \pm 0.02$ & $7.93 \pm 0.02$ & $7.8 \pm 0.3$ & $7.7 \pm 0.2$ & $7.77 \pm 0.03$ \\
\hline \multicolumn{6}{|l|}{ Tarhana sample $\mathbf{C}$} \\
\hline \multicolumn{6}{|l|}{ Microorganisms, $\log _{10} \mathrm{cfu} / \mathrm{g}$} \\
\hline TMAB & $7.41 \pm 0.01$ & $8.04 \pm 0.02$ & $7.8 \pm 0.1$ & $7.67 \pm 0.02$ & $7.84 \pm 0.05$ \\
\hline Yeast and Mould & $7.36 \pm 0.04$ & $8.04 \pm 0.03$ & $7.82 \pm 0.01$ & $7.70 \pm 0.02$ & $7.77 \pm 0.02$ \\
\hline Coliform & $2.6 \pm 0.2$ & $<2.0$ & $<2.0$ & $<2.0$ & $<2.0$ \\
\hline S. aureus & $2.5 \pm 0.3$ & $1.98 \pm 0.08$ & $<2.0$ & $<2.0$ & $<2.0$ \\
\hline LAB (MRS) & $8.5 \pm 0.1$ & $8.00 \pm 0.05$ & $7.73 \pm 0.02$ & $7.73 \pm 0.02$ & $7.95 \pm 0.03$ \\
\hline M 17 & $8.51 \pm 0.04$ & $8.0 \pm 0.1$ & $7.73 \pm 0.08$ & $7.73 \pm 0.08$ & $7.81 \pm 0.02$ \\
\hline
\end{tabular}

A: Control tarhana sample (prepared with yoghurt), B: tarhana sample with 50\% kefir (based on the yoghurt used), C: tarhana sample with $100 \%$ kefir (based on the yoghurt used)

pressure and water activity restricted their grow. The highest TMAB content was found in sample $\mathrm{F}$ (Table $4 \mathrm{e})$ as the low storage temperature $\left(4^{\circ} \mathrm{C}\right)$ slowed the death of bacteria. However, the lowest TMAB content was found in sample $\mathrm{S}$ due to the high osmotic pressure and the low water activity of this sample. Also, due to the very low water activity of sample $\mathrm{C}$, the lowest LAB count was determined in this sample. However, there was not found any significant difference in LAB content among $\mathrm{N}, \mathrm{A}$ and $\mathrm{F}$ samples (Table 4e). Concerning yeast and moulds content, sample $\mathrm{F}$ had a significant higher population of yeast and moulds than samples $\mathrm{S}, \mathrm{N}$, $\mathrm{A}$ and $\mathrm{C}$ (Table 4e). This could be due to the fact that yeast and moulds of Tarhana have survived in low temperatures. Degirmencioglu et al. (2005) examined the use of Tarhana herb (Echinophora sibthorpiana) on Tarhana fermentation. Tarhana herb (Echinophora sibthorpiana) was used as a spice in Tarhana production. It is known to have a pleasant flavour and helps the development of some microorganisms. Tarhana samples were made by different ratios of Tarhana herb $(0.5,1$ and $1.5 \%)$.
Tarhana dough was fermented at $25^{\circ} \mathrm{C}$ for $4 \mathrm{~d}$. During Tarhana fermentation, the lactic acid bacteria (LAB) from yoghurt and the $S$. cerevisiae from the baker's yeast were the main microorganisms found and responsible for its fermentation. The LAB counts increased during Tarhana fermentation in all the Tarhana samples made by the addition of Tarhana herb (TH). The highest count of LAB was found after 4 days of fermentation in sample $\mathrm{S} 2$ that was made by adding $0.5 \%$ of TH. On the contrary, the yeast populations of all samples of dough with $\mathrm{TH}$ increased during the first two days of fermentation and decreased thereafter. However, their number did not decrease under their initial number. Also, the LAB counts of the control sample S1 that was made without the addition of Tarhana herb $(\mathrm{TH})$ reduced during fermentation. The results of the present study showed that Tarhana herb (Echinophora sibthorpiana) prevented the decrease in the LAB counts during fermentation and in yeast population during the first two day of fermentation. Finally, the microbial populations of the dried and ground 
Tarhana samples made with and without the addition of Tarhana herb were shown in Table 4a. Sengun et al. (2009) studied the mesophilic and thermophilic lactic acid bacteria (LAB) profile in Tarhana samples taken from eight different cities of the Aegean Turkish region. The samples were collected at different fermentation time as well as from the final product (dried Tarhana). Lactic acid bacteria $(\mathrm{LAB})$ were enumerated in three different media (MRS, M-17 and SAB) at two different temperatures $\left(30^{\circ} \mathrm{C}\right.$ and $\left.42^{\circ} \mathrm{C}\right)$. Generally, it was shown that the LAB counts in MRS and M-17 media were similar. However, lower counts were determined in SAB media. At the beginning of fermentation (F0) the LAB count was high while it was limited throughout fermentation. The highest LAB values $(\mathrm{cfu} / \mathrm{g})$ were found during the first two days of fermentation (Table 5). Later on the LAB counts didn't change or decreased probably due to the lack of nutrients. The drying of Tarhana resulted in several log units' reduction of the LAB counts due to the decreasing moisture content of the product. For different incubation temperatures the counts of $\mathrm{LAB}$ were found to be similar with the exception of samples $\mathrm{C}$ and $\mathrm{E}$. In sample $\mathrm{C}$ approximately $1 \log \mathrm{cfu} / \mathrm{g}$ lower LAB counts were found on media incubated at $42^{\circ} \mathrm{C}$ as compared to media incubated at $30^{\circ} \mathrm{C}$. Nevertheless, in sample E, $1 \log \mathrm{cfu} / \mathrm{g}$ higher LAB were observed on media incubated at $42^{\circ} \mathrm{C}$ than on media incubated to $30^{\circ} \mathrm{C}$. These authors also studied for the first time by molecular techniques the predominant lactic acid bacteria (LAB) that were isolated during Tarhana processing. The microorganism Pediococcus acidilactici was found to be the $27 \%$ of the microbial isolates. However, $19 \%$ of the microbial isolates were identified as Streptococcus thermophilus, $19 \%$ as Lactobacillus fermentum, $12 \%$ as Enterococcus faecium, $7 \%$ as Pediococcus pentosaceus, $5 \%$ as Leuconostoc pseudomesenteroides, $4 \%$ as Weissella cibaria, $2 \%$ as Lactobacillus plantarum, $2 \%$ as Lactobacillus delbrueckii spp. bulgaricus, $2 \%$ as Leuconostoc citreum, $1 \%$ as Lactobacillus paraplantarum and $0.5 \%$ as Lactobacillus casei. The bacteria P. acidilactici and Streptococcus thermophilus were found in most of the examined samples with yoghurt used for Tarhana preparation to be the main source of these bacteria. One hundred and fifty Gram-positive, catalase negative microorganisms were detected in different stages of Tarhana dough. In dried Tarhana samples, 16 isolates were found. However, from yoghurt and broken wheat used in Tarhana production, 50 isolates and 10 isolates were taken, respectively. Settanni et al. (2011) studied the lactic acid bacteria (LAB) and yeasts evolution during Tarhana fermentation. Tarhana was produced with some pasteurized ingredients and carried out at $30^{\circ} \mathrm{C}$ and $40^{\circ} \mathrm{C}$. During Tarhana fermentation LAB and yeasts varied between $10^{7}$ and $10^{8}$ colony forming units $\mathrm{cfu} / \mathrm{g}$. However, no coliform bacteria were found. The isolated lactic acid bacteria were grouped according to their phenotypic and polymorphic characteristics. Pediococcus acidilactici, Lactobacillus plantarum and Lactobacillus brevis were the identified bacterial strains. The pasteurization that was done to the vegetable ingredients (except wheat flour) improved the hygienic conditions of Tarhana but did not influence the $\mathrm{LAB}$ evolution during fermentation. However, no statistically significant differences in LAB counts were found between the two Tarhana preparations that took place under $30^{\circ} \mathrm{C}$ or $40^{\circ} \mathrm{C}$ fermentation temperature (Table $3 \mathrm{~b}$ ). Sengun and Karapinar (2012) studied the microbiological characteristics of Tarhana and its raw material. Tarhana samples were taken from eight Turkish regions. Tarhana samples were collected during the fermentation process and after its drying. The microbial results of eight Tarhana samples from different Turkish cities at the beginning of fermentation period are shown in Table $4 \mathrm{~b}$. The results showed that none of the Tarhana samples collected contained at the beginning of fermentation the microorganisms Staphylococcus aureus and Escherichia coli. Three of the examined samples, the $\mathrm{A}, \mathrm{B}$ and $\mathrm{C}$, contained low amounts of the microorganism Clostridium perfringens in levels that were not sufficient to produce any toxin. Samples E, F and G were found to be positive for Salmonella where samples B, C contained B. cereus $\sim 10^{2}$ cfug $^{-1}$ level and G. Also, no Salmonella, $C$. perfringens, $S$. aureus, B. cereus, coliform and $E$. coli were detected after $24 \mathrm{~h}$ fermentation period in any of the examined samples. As the fermentation phase was completed the drying process was applied. As a result of the drying process the aerobic plate count (APC) was significantly decreased in the examined Tarhana samples except from samples E and $\mathrm{F}$ which had the shortest time of fermentation. 
Table 4a. Microbiological results of Tarhana samples and microbial changes during tarhana fermentation (References: Degirmencioglu et al. 2005)

\begin{tabular}{lcccc}
\hline Group of microorganisms, $\mathbf{c f u} / \mathbf{g}$ & \multicolumn{4}{c}{ Tarhana's sample code } \\
& $\mathrm{S} 1$ & $\mathrm{~S} 2$ & $\mathrm{~S} 3$ & $\mathrm{~S} 4$ \\
\hline TB & $7.10 \times 10^{6} \pm 0.04$ & $2.40 \times 10^{6} \pm 0.03$ & $2.37 \times 10^{6} \pm 0.03$ & $1.75 \times 10^{6} \pm 0.003$ \\
LAB & $1.27 \times 10^{6} \pm 0.04$ & $1.78 \times 10^{6} \pm 0.01$ & $1.22 \times 10^{6} \pm 0.04$ & $1.47 \times 10^{6} \pm 0.03$ \\
Y & $4.05 \times 10^{5} \pm 0.001$ & $5.85 \times 10^{6} \pm 0.002$ & $1.13 \times 10^{6} \pm 0.025$ & $1.51 \times 10^{6} \pm 0.045$ \\
\hline
\end{tabular}

S1: Standard tarhana sample without tarhana herb, S2: tarhana sample with $0.5 \%$ tarhana herb, S3: tarhana sample with $1.0 \%$ tarhana herb, S4: tarhana sample with $1.5 \%$ tarhana herb.

Table 4b. Microbiological results of Tarhana samples and microbial changes during tarhana fermentation (References: Sengun and Karapinar 2012)

\begin{tabular}{lcccccccc}
\hline Tarhana dough & \multicolumn{9}{c}{ Samples of Tarhana dough (at the beginning of the fermentation) } \\
Microorganisms, cfu/g & $\mathrm{A}$ & $\mathrm{B}$ & $\mathrm{C}$ & $\mathrm{D}$ & $\mathrm{E}$ & $\mathrm{F}$ & $\mathrm{G}$ & $\mathrm{H}$ \\
\hline Staphylococcus aureus & $<10$ & $<10$ & $<10$ & $<10$ & $<10$ & $<10$ & $<10$ & $<10$ \\
C. perfringens & $1.0 \times 10^{1}$ & $7.0 \times 10^{1}$ & $0.5 \times 10^{1}$ & $<10$ & $<10$ & $<10$ & $<10$ & $<10$ \\
Salmonella spp. & negative & negative & negative & negative & positive & positive & positive & negative \\
Bacillus cereus & $<10$ & $5.0 \times 10^{2}$ & $1.0 \times 10^{2}$ & $<10$ & $<10$ & $<10$ & $2.5 \times 10^{2}$ & $<10$ \\
Aerobic plate count & $4.1 \times 10^{6}$ & $7.0 \times 10^{6}$ & $4.0 \times 10^{7}$ & $3.5 \times 10^{7}$ & $2.3 \times 10^{6}$ & $1.6 \times 10^{5}$ & $8.0 \times 10^{6}$ & $1.6 \times 10^{6}$ \\
Microorganisms, mnp/g & $\mathrm{A}$ & $\mathrm{B}$ & $\mathrm{C}$ & $\mathrm{D}$ & $\mathrm{E}$ & $\mathrm{F}$ & $\mathrm{G}$ & $\mathrm{H}$ \\
Coliform & $<3$ & $<3$ & 4 & 15 & $<3$ & $<3$ & 45 & $<3$ \\
Escherichia coli & $<3$ & $<3$ & $<3$ & $<3$ & $<3$ & $<3$ & $<3$ & $<3$ \\
\hline
\end{tabular}

MPN: Most Probable Number, Turkish cities/region/site: A: Aydin/Incirliova, B: Milas/Bordum-Gundogan village, C: Izmir/Hatay, D: Manisa/Golmarmara-Tiyenli village, E: Izmir/Urla-Gulbahce village, F: Izmir/Cesme-Barbaros village, G: Usak/City Center, H: Isparta/Sarkikaraagac

Table 4c. Microbiological results of Tarhana samples and microbial changes during tarhana fermentation (References: Hendek Ertop et al. 2019)

\begin{tabular}{lccccccccc}
\hline $\begin{array}{l}\text { Group of } \\
\text { microorganisms, cfu/g }\end{array}$ & $\mathrm{T} 1$ & $\mathrm{~T} 2$ & $\mathrm{~T} 3$ & $\mathrm{~T} 4$ & $\mathrm{~T} 5$ & $\mathrm{~T} 6$ & $\mathrm{~T} 7$ & $\mathrm{~T} 8$ & $\mathrm{~T} 9$ \\
\hline Aerobic LAB & $42 \times 10^{5}$ & $11 \times 10^{6}$ & $34 \times 10^{4}$ & $50 \times 10^{5}$ & $11 \times 10^{3}$ & $24 \times 10^{5}$ & - & $95 \times 10^{5}$ & $56 \times 10^{4}$ \\
Anaerobic LAB & $78 \times 10^{5}$ & $40 \times 10^{6}$ & - & - & $27 \times 10^{6}$ & $12 \times 10^{6}$ & - & $15 \times 10^{6}$ & - \\
Yeast & $43 \times 10^{3}$ & $26 \times 10^{4}$ & $24 \times 10^{3}$ & $72 \times 10^{3}$ & $28 \times 10^{4}$ & $30 \times 10^{6}$ & - & $76 \times 10^{5}$ & $30 \times 10^{3}$ \\
\hline
\end{tabular}

Regions/districts of Kastamonu Turkey: T1: Akdogan, T2: Azdavay, T3: Bozkurt, T4: City Center, T5: Daday, T6: Devrekani, T7: Inebolu, T8: Pehlivan, T9: Taskopru

Table 4d. Microbiological results of Tarhana samples and microbial changes during tarhana fermentation (References: Arslan-Tontul et al. 2018)

\begin{tabular}{lcccc}
\hline & \multicolumn{4}{c}{ Type of Tarhana } \\
\hline Group of microorganisms, $\log _{\mathbf{1 0}} \mathbf{~ c f u} / \mathbf{g} \pm \mathbf{S E}$ & $\mathrm{Y}$ & \multicolumn{3}{c}{$\mathrm{K}$} \\
Yeast & $7.75 \pm 0.06$ & $7.71 \pm 0.08$ & \\
LAB & $7.45 \pm 0.07$ & $7.84 \pm 0.19$ & \\
TMAB & $7.72 \pm 0.08$ & $7.76 \pm 0.08$ & \\
\hline & \multicolumn{4}{c}{ Fermentation time, d } \\
\hline Group of microorganisms, $\log _{\mathbf{1 0}} \mathbf{~ c f u} / \mathbf{g} \pm \mathbf{S E}$ & 0 & 1 & 2 & 3 \\
Yeast & $7.51 \pm 0.04$ & $7.91 \pm 0.02$ & $7.91 \pm 0.03$ & $7.57 \pm 0.03$ \\
LAB & $7.38 \pm 0.03$ & $7.67 \pm 0.06$ & $7.55 \pm 0.15$ & $8.26 \pm 0.20$ \\
TMAB & $7.49 \pm 0.02$ & $7.96 \pm 0.04$ & $7.92 \pm 0.06$ & $7.64 \pm 0.05$ \\
\hline
\end{tabular}


Table 4e. Microbiological results of Tarhana samples and microbial changes during tarhana fermentation (References: Erbas et al. 2005)

\begin{tabular}{|c|c|c|c|c|c|c|c|}
\hline Tarhana & & & Fer & entation ti & e, d & & \\
\hline $\begin{array}{l}\text { Group of microorganisms, } \\
\log _{10} \mathrm{cfu} / \mathrm{g}\end{array}$ & 0 & 1 & 2 & 3 & & & \\
\hline $\begin{array}{l}\text { TMAB } \\
\text { (Total microbial bacteria) }\end{array}$ & $6.43 \pm 0.07$ & $6.58 \pm 0.03$ & $6.13 \pm 0.16$ & $5.95 \pm 0.14$ & & & \\
\hline LAB (Lactobacillus spp.) & $6.47 \pm 0.01$ & $6.51 \pm 0.01$ & $5.94 \pm 0.04$ & $5.44 \pm 0.03$ & & & \\
\hline $\begin{array}{l}\text { Yeast and moulds } \\
\text { Coliform }\end{array}$ & $\begin{array}{l}6.59 \pm 0.11 \\
\text { n.d. }\end{array}$ & $\begin{array}{l}6.26 \pm 0.11 \\
\text { n.d. }\end{array}$ & $\begin{array}{c}6.15 \pm 0.02 \\
\text { n.d. }\end{array}$ & $\begin{array}{l}5.78 \pm 0.08 \\
\text { n.d. }\end{array}$ & & & \\
\hline $\begin{array}{l}\text { Group of microorganisms, } \\
\log _{10} \mathrm{cfu} / \mathrm{g}\end{array}$ & 0 & 1 & 2 & 3 & 4 & 5 & 6 \\
\hline TMAB & $5.95 \pm 0.15$ & $4.27 \pm 0.38$ & $3.91 \pm 0.44$ & $3.62 \pm 0.43$ & $3.36 \pm 0.49$ & $2.75 \pm 0.39$ & $2.30 \pm 0.38$ \\
\hline LAB & $5.44 \pm 0.10$ & $4.17 \pm 0.50$ & $3.82 \pm 0.59$ & $3.67 \pm 0.57$ & $3.52 \pm 0.57$ & $3.38 \pm 0.57$ & $3.17 \pm 0.58$ \\
\hline Yeast and Moulds & $5.78 \pm 0.03$ & $2.38 \pm 0.61$ & $2.14 \pm 0.57$ & $2.08 \pm 0.54$ & $1.91 \pm 0.53$ & $1.80 \pm 0.53$ & $1.77 \pm 0.52$ \\
\hline $\begin{array}{l}\text { Group of microorganisms, } \\
\log _{10} \mathrm{cfu} / \mathrm{g}\end{array}$ & $\mathrm{N}$ & A & $\mathrm{F}$ & $\mathrm{S}$ & $\mathrm{C}$ & & \\
\hline TMAB & $3.59 \pm 0.51$ & $3.52 \pm 0.25$ & $4.94 \pm 0.21$ & $2.64 \pm 0.43$ & $2.99 \pm 0.37$ & & \\
\hline LAB & $5.01 \pm 0.10$ & $4.99 \pm 0.12$ & $5.07 \pm 0.08$ & $2.61 \pm 0.36$ & $1.74 \pm 0.43$ & & \\
\hline Yeast and molds & $1.68 \pm 0.46$ & $1.68 \pm 0.46$ & $5.26 \pm 0.13$ & $2.45 \pm 0.44$ & $1.68 \pm 0.46$ & & \\
\hline
\end{tabular}

In dried Tarhana samples the aerobic plate count (APC) ranged from $1.4 \times 10^{3} \mathrm{cfu} / \mathrm{g}$ to $4.0 \times 10^{6} \mathrm{cfu} / \mathrm{g}$. Concerning the presence of $C$. perfringens it was observed that only one Tarhana sample, the sample E, which does not contain C. perfigens at the beginning of fermentation, contained this microorganism at low levels $\left(5.0 \times 10^{1} \mathrm{cfu} / \mathrm{g}\right)$ at the dried form of Tarhana. This is due to the fact that except from possible contaminated raw materials that affected the microbial quality of Tarhana, some contamination could also occur during the drying process. Also, there were not detected any of the microorganisms Salmonella, S. aureus, B. cereus, coliform and E.coli in the dried Tarhana samples. Concluding, this study showed that the microbial characteristics of Tarhana food were affected by the raw materials, the fermentation time and the techniques used for Tarhana food making. Kumral (2015) in order to make better the nutritional benefits of Tarhana used whole wheat and chickpea flours in Tarhana production. These flours were the only flour source for making Tarhana. Concerning the study of the microbiological characteristics, flour type and fermentation time were found to have a significant effect on yeast growth. Generally, yeasts increased their number during the first two days of fermentation. Their increase showed that yeasts fermented the free sugars found in the Tarhana mixture and were correlated in the process of Tarhana fermentation. The highest yeast number was found in $48 \mathrm{~h}$ Tarhana sample made by chickpea flour. However, in the end of Tarhana fermentation their number dropped below their initial number. This was due to the significant increase of sample acidity. Also, flour type and fermentation time significantly affected the mesophilic lactic acid bacteria (LAB) population. However, the development of thermophilic lactic acid bacteria (LAB) was not affected by the flour type but it was significantly affected by the fermentation time. In whole wheat flour Tarhana (WWFT) and in Tarhana made by chickpea flour (CFT) a significant decrease in the number of thermophilic LAB was observed. Concluding, the results of this study showed that the yeasts were involved in Tarhana fermentation despite the fact that their number was affected by the increased samples acidity. Also, there was not found any similarity in the behaviour of mesophilic and thermophilic LAB. Generally, the growth of LAB was influenced by the fermentable carbon and nitrogen sources availability of the samples, the acid degree and the fermentation time and temperature. Kivanc and Funda (2016) studied the microbial changes during Tarhana dough fermentation. At the beginning of fermentation, yeasts, moulds, TMAB (total mesophilic aerobe bacteria) and LAB (lactic acid bacteria) counts were found to be similar. The 
lactic acid bacteria (LAB) and yeasts which are known to contribute to the flavour and taste of Tarhana by producing lactic acid, ethanol, carbon dioxide, increased the first 5 days of fermentation. In Tarhana dough, the lactic acid bacteria increased from $1.32 \times 10^{2}$ to $4.20 \times 10^{4} \mathrm{cfu} / \mathrm{g}$ and the yeasts from $3.45 \times 10^{1}$ to $2.40 \times 10^{5} \mathrm{cfu} / \mathrm{g}$. The TMAB count was found to increase rapidly during the first $3 \mathrm{~d}$ of fermentation. A number of 640 bacteria were isolated during Tarhana dough fermentation. From these bacteria 623 were found to be lactic acid bacteria. Also, a number of 540 yeasts were isolated. The bacteria Lactococcus lactis spp. lactis, Leuconostoc mesenteroides, Lactobacillus acidophilus, Enterococcus durans, Pediococcus spp., Lactobacillus delbrueckii ssp. lactis and Lactobacillus paracasei bacteria were found to contribute to Tarhana dough fermentation as well as the yeasts Kluyveromyces marxianus, Yarrowia lipolytica, Pichia membranaefaciens, Pichia mexicana, Pichia angusta, Debaryomyces hansenii, Candida sorboxylosa, Candida fluviatilis, Saccharomyces cerevisiae. The microorganisms $E$. durans, L. plantarum, S. cerevisiae, K. marxianus and $Y$. lipolytica were the main microbial strains found at the end stages of Tarhana fermentation. Sismek (2017) studied the lactic acid bacteria evolution during the fermentation of homemade and commercially made Tarhana. The results of this study showed that commercially prepared Tarhana dough was fermented with a higher Lactobacillus spp. diversity than homemade one. The microorganisms Lactobacillus casei, L. alimentarius, $L$. fabifermentas and L. paralimentarius were directly identified from the fermentation of the Tarhana dough that was commercially produced. This Tarhana dough showed a higher amount of different lactic acid bacteria (LAB) strains than the homemade Tarhana dough. This showed that commercially Tarhana dough samples could have a high LAB diversity. L. plantarum and L. brevis were the predominant microbial strains of the Tarhana dough samples examined. Four homemade Tarhana dough samples named A, B, C D, were examined. Also, four commercially Tarhana dough samples were tested named E, F, G and $\mathrm{H}$. In dough A, the microorganisms $L$. namurensis, $P$. acidilactici, L. mindensis and $S$. thermophilus appeared from day 1 to day 10 of fermentation.
However, in the same sample, the L. plantarum was found through the whole fermentation process. In dough B, the microorganisms $L$. crispatus and $S$. thermophilus were present in all the fermentation periods. L. crispatus was found to be unique for this sample. In dough C, L. lactis, Leu. mesenteroides and L. bulgaricus were found to be present in all the fermentation process. However, L. plantarum, $L$. alimentarius, L. brevis and L. sanfranciscensis were also found to be present after the 3rd day of fermentation. Finally, in dough D, the microorganisms L. plantarum, L. lactis and L. casei were detected throughout the fermentation process. Nevertheless, L. namurensis, L. bulgaricus and $P$. acidilactici disappeared by the 5 th $\mathrm{d}$ of fermentation. L. plantarum was stably found in both homemade and commercially made tarhana dough samples. However, L. brevis was found in the commercially made tarhana dough. Also, in the commercially Tarhana dough samples, $L$. alimentarious increased with fermentation, while $L$. bulgaricus and $S$. thermophilus gradually decreased. Commercially Tarhana dough had a large diversity of lactic acid bacteria, mainly of sourdough-associated Lactobacillus strains. The microorganisms $L$. plantarum, $L$. brevis and $L$. alimantarius were stably found in commercially prepared Tarhana. These microorganisms could be used as potential starter cultures at the industrial Tarhana production. Arslan-Tontul et al. (2018) studied the use of kefir, yoghurt and their combination in the production of wet Tarhana in order to develop the nutritional value of the final product. The lactic acid bacteria (LAB) count increased with the addition of kefir (Table 4d). However, fermentation time significantly affected the counts of all microorganisms studied (yeast, LAB and TMAB). When kefir was used in the production of Tarhana the LAB count increased continuously and reached $8.26 \mathrm{log} \mathrm{cfu} / \mathrm{g}$ at the end (3rd d) of fermentation time (Table 4d). This was possibly due to the high amount of LAB found in kefir $\left(7.02 \log _{10} \mathrm{cfu} / \mathrm{g}\right)$ and also to the fact that Tarhana dough had a high amount of micronutrients that helped LAB development. The mean TMAB counts of the examined Tarhana samples was found to be $7.75 \log _{10} \mathrm{cfu} / \mathrm{g}$. TMAB count was found to increase on day one of fermentation and decreased afterwards. At the end of fermentation (3rd d) 
TMAB count ranged from 7.64 to $7.96 \mathrm{cfu} / \mathrm{g}$ (Table $4 d)$. This decrease is possibly due to the increase of product acidity and to the formation of substances such as carbon dioxide, diacetyl and ethanol in the fermentation media. At the end of fermentation (3rd d) total yeast, LAB and total mesophilic bacteria (TMAB) populations were 7.57, 8.26 and $7.64 \log _{10}$ $\mathrm{cfu} / \mathrm{g}$, respectively (Table 4). This study showed that kefir used as a yoghurt replacement in Tarhana production increased the count of lactic acid bacteria (LAB). However, the addition of kefir insignificantly affected the count of yeast and TMAB of wet Tarhana. Dermirci et al. (2018) studied the effect of using kefir as substitute for yoghurt, partially or completely, in Tarhana production. The Tarhana samples studied were: A: Control Tarhana-prepared with yoghurt, B: Tarhana with $50 \%$ kefir depending on the amount of yoghurt used and C: Tarhana with 100\% kefir based on the yoghurt used. At the beginning of fermentation almost the same microbial concentrations were found in all Tarhana samples (Table 3c). Total mesophilic aerobic bacteria (TMAB) counts significantly increased from day 0 to day 1 of fermentation. This was due to the low acidity and the high $\mathrm{pH}$ value of the dough at day one of fermentation (Table3). As a result of acid formation, TMAB counts decreased thereafter (Table 3c). The lactic acid bacteria (LAB) counts were found to continuously decrease during the day 5 of fermentation (Table 3c). The population of LAB groups on M17 and MRS agar of Tarhana supplemented with $100 \%$ kefir instead of yoghurt (sample C) was higher than that of the rest Tarhana samples during fermentation (Table 3c). However, the final counts of LAB of the Tarhana dough samples $\mathrm{B}$ and $\mathrm{C}$ were similar and higher than those of the standard Tarhana (A) (Table 3c). Concerning yeasts and moulds counts comparable results were found. However, the highest counts of yeasts and moulds were found at a first day of fermentation. The increase of yeast and moulds population on day one of fermentation showed the involvement of yeast in Tarhana fermentation. The most known fermented milk product 'yoghurt' is used in the production of Tarhana due to its lactic acid content. The results of this study showed that kefir, another important fermented milk product, could also be used as an alternative substance in Tarhana fermentation. The addition of kefir increased the fermentation activity of tarhana dough as compared to the control Tarhana dough that was prepared with yoghurt (sample A). Hendek Ertop et al. (2019) examined the microbiological characteristics of wet Tarhana, a traditional fermented product that is prepared with wheat flour, yoghurt, Tarhana herb (Echiophora sibthorpiana) and some chopped vegetables and spices. To prepare dough, all ingredients are kneaded thoroughly and then the dough set aside for fermentation at room temperature for around ten days. During this process, the spontaneous fermentation takes place. The basic difference of wet Tarhana from other Tarhana types is that it is prepared without a drying step. Wet Tarhana is stored in glass jars. The Tarhana samples of this study were produced in the same season on August and were collected from 9 different regions of Kastamonu Turkey; Akdogan (T1 sample), Azdavay (T2 sample), Bozkurt (T3 sample), City Center (T4 sample), Daday (T5 sample), Devrekani (T6 sample), Inebolu (T7 sample), Pehlivan (T8 sample) and Taskopru (T9 sample) districts. The number of aerobic Lab (cfu/g), anaerobic LAB (cfu/g) and yeast (cfu/g) are shown in Table 4c. The number of microorganisms differed according to the Tarhana sample. In sample T7, there was not observed any growth of the examined microorganisms. Also, the anaerobic LAB didn't grow in samples T3, T4 and T9. Generally, $10^{5}-10^{6} \mathrm{cfu} / \mathrm{g}$ anaerobic LAB, $10^{3}-10^{6}$ $\mathrm{cfu} / \mathrm{g}$ aerobic LAB and $10^{3}-10^{6} \mathrm{cfu} / \mathrm{g}$ yeast were found in the examined Tarhana samples (Table 4c). Wet Tarhana was found to have a more microbial load than dry Tarhana. 
Table 5. Lactic acid bacteria (LAB) counts (cfu/g) determined on MRS agar at $30^{\circ} \mathrm{C}$ or $40^{\circ} \mathrm{C}$, on $\mathrm{M}-17$ agar on $30^{\circ} \mathrm{C}$ or $40^{\circ} \mathrm{C}$ and on SAB medium (Reference: Sengun et al. 2009)

\begin{tabular}{|c|c|c|c|c|c|c|c|c|c|c|}
\hline $\begin{array}{l}\text { Tarhana samples } \\
\text { (Sampling region/site) }\end{array}$ & $\begin{array}{c}\text { Fer- } \\
\text { men- } \\
\text { tation } \\
\text { time, } d\end{array}$ & & & & Sampl & time, $\mathrm{d}$ & & & & $\begin{array}{c}\text { Dried } \\
\text { tarhana }\end{array}$ \\
\hline $\begin{array}{l}\text { Sample A } \\
\text { (Aydin/Incirliova) }\end{array}$ & 2 & F0 & $\mathrm{F} 1$ & $\mathrm{~F} 2$ & F3 & F4 & F6 & F15 & F21 & $\mathrm{T}$ \\
\hline $\mathrm{LAB}$ on MRS agar $30^{\circ} \mathrm{C}$ & & 6.6 & 7.3 & 7.2 & & & & & & 4.4 \\
\hline $\mathrm{LAB}$ on $\mathrm{M}-17$ agar $30^{\circ} \mathrm{C}$ & & 8.2 & 7.1 & 6.5 & & & & & & 3.0 \\
\hline $\mathrm{SAB}$ & & 10 & 10 & 10 & & & & & & 10 \\
\hline LAB on MRS agar $40^{\circ} \mathrm{C}$ & & 6.9 & 6.0 & 6.4 & & & & & & 3.4 \\
\hline LAB on M-17 agar $40^{\circ} \mathrm{C}$ & & 8.5 & 7.6 & 6.9 & & & & & & 2.0 \\
\hline SAB & & 10 & 10 & 10 & & & & & & 10 \\
\hline $\begin{array}{l}\text { Sample B (Milas/Bordum- } \\
\text { Gundogan village) }\end{array}$ & 4 & F0 & $\mathrm{F} 1$ & $\mathrm{~F} 2$ & F3 & F4 & F6 & F15 & F21 & $\mathrm{T}$ \\
\hline LAB on MRS agar $30^{\circ} \mathrm{C}$ & & 6.6 & 7.3 & 6.3 & & 6.5 & & & & 3.2 \\
\hline $\mathrm{LAB}$ on $\mathrm{M}-17$ agar $30^{\circ} \mathrm{C}$ & & 6.6 & 7.3 & 6.2 & & 6.6 & & & & 3.3 \\
\hline SAB & & 2.4 & 3.1 & 3.0 & & 3.5 & & & & 4.8 \\
\hline LAB on MRS agar $40^{\circ} \mathrm{C}$ & & 6.7 & 7.8 & 7.2 & & 7.2 & & & & 1.8 \\
\hline $\mathrm{LAB}$ on $\mathrm{M}-17$ agar $40^{\circ} \mathrm{C}$ & & 6.7 & 7.1 & 5.6 & & 6.1 & & & & 3.7 \\
\hline SAB & & 2.0 & 3.1 & 1.7 & & 3.3 & & & & 3.1 \\
\hline $\begin{array}{l}\text { Sample C } \\
\text { (Izmir/Hatay) }\end{array}$ & 6 & F0 & $\mathrm{F} 1$ & $\mathrm{~F} 2$ & F3 & F4 & F6 & F15 & F21 & $\mathrm{T}$ \\
\hline LAB on MRS agar $30^{\circ} \mathrm{C}$ & & 7.7 & 7.7 & 7.5 & & 7.4 & 7.3 & & & 6.0 \\
\hline LAB on $\mathrm{M}-17$ agar $30^{\circ} \mathrm{C}$ & & 6.8 & 7.4 & 6.5 & & 6.0 & 5.3 & & & 4.5 \\
\hline $\mathrm{SAB}$ & & 4.8 & 4.9 & 4.8 & & 4.1 & 4.7 & & & 5.0 \\
\hline LAB on MRS agar $40^{\circ} \mathrm{C}$ & & 6.8 & 6.9 & 7.0 & & 6.7 & 7.2 & & & 4.9 \\
\hline $\mathrm{LAB}$ on $\mathrm{M}-17$ agar $40^{\circ} \mathrm{C}$ & & 5.3 & 6.5 & 5.3 & & 5.1 & 4.9 & & & 3.7 \\
\hline $\mathrm{SAB}$ & & 4.7 & 4.6 & 6.8 & & 5.0 & 4.6 & & & 4.0 \\
\hline $\begin{array}{l}\text { Sample D (Manisa/ } \\
\text { Golmarmara-Tiyenli village) }\end{array}$ & 15 & F0 & $\mathrm{F} 1$ & $\mathrm{~F} 2$ & $\mathrm{~F} 3$ & $\mathrm{~F} 4$ & F6 & F15 & F21 & $\mathrm{T}$ \\
\hline LAB on MRS agar $30^{\circ} \mathrm{C}$ & & 7.5 & 7.3 & 7.3 & & 7.0 & 6.2 & 5.2 & & 4.2 \\
\hline $\mathrm{LAB}$ on $\mathrm{M}-17$ agar $30^{\circ} \mathrm{C}$ & & 7.1 & 7.4 & 7.0 & & 6.4 & 6.8 & 5.0 & & 4.3 \\
\hline SAB & & 6.3 & 6.3 & 4.9 & & 5.0 & 5.5 & 3.3 & & 4.1 \\
\hline LAB on MRS agar $40^{\circ} \mathrm{C}$ & & 7.3 & 7.0 & 4.4 & & 4.8 & 6.5 & 3.0 & & 3.7 \\
\hline $\mathrm{LAB}$ on $\mathrm{M}-17$ agar $40^{\circ} \mathrm{C}$ & & 7.5 & 7.1 & 6.7 & & 5.6 & 6.5 & 4.0 & & 4.0 \\
\hline $\mathrm{SAB}$ & & 5.5 & 5.7 & 4.2 & & 3.5 & 2.9 & 4.2 & & 2.7 \\
\hline $\begin{array}{l}\text { Sample E (Izmir/Urla- } \\
\text { Gulbahce village) }\end{array}$ & 1 & F0 & $\mathrm{F} 1$ & $\mathrm{~F} 2$ & F3 & F4 & F6 & F15 & F21 & $\mathrm{T}$ \\
\hline $\mathrm{LAB}$ on MRS agar $30^{\circ} \mathrm{C}$ & & 6.7 & 6.6 & & & & & & & 6.5 \\
\hline $\mathrm{LAB}$ on $\mathrm{M}-17$ agar $30^{\circ} \mathrm{C}$ & & 5.1 & 7.1 & & & & & & & 6.1 \\
\hline SAB & & 2.9 & 2.1 & & & & & & & 3.6 \\
\hline LAB on MRS agar $40^{\circ} \mathrm{C}$ & & 7.6 & 6.8 & & & & & & & 3.8 \\
\hline $\mathrm{LAB}$ on $\mathrm{M}-17$ agar $40^{\circ} \mathrm{C}$ & & 7.7 & 6.6 & & & & & & & 5.9 \\
\hline SAB & & 5.3 & 5.3 & & & & & & & 3.4 \\
\hline $\begin{array}{l}\text { Sample F (Izmir/Cesme- } \\
\text { Barbaros village) }\end{array}$ & 1 & F0 & $\mathrm{F} 1$ & $\mathrm{~F} 2$ & $\mathrm{~F} 3$ & F4 & F6 & F15 & F21 & $\mathrm{T}$ \\
\hline LAB on MRS agar $30^{\circ} \mathrm{C}$ & & 10 & 10 & & & & & & & 10 \\
\hline LAB on M-17 agar $30^{\circ} \mathrm{C}$ & & 6.6 & 5.9 & & & & & & & 10 \\
\hline SAB & & 1.5 & 1.8 & & & & & & & 1.5 \\
\hline LAB on MRS agar $40^{\circ} \mathrm{C}$ & & 10 & 10 & & & & & & & 1.2 \\
\hline $\mathrm{LAB}$ on $\mathrm{M}-17$ agar $40^{\circ} \mathrm{C}$ & & 6.5 & 5.9 & & & & & & & 10 \\
\hline SAB & & 1.8 & 1.8 & & & & & & & 10 \\
\hline
\end{tabular}


Table 5 - Continuation. Lactic acid bacteria (LAB) counts ( $\mathrm{cfu} / \mathrm{g})$ determined on MRS agar at $30^{\circ} \mathrm{C}$ or $40^{\circ} \mathrm{C}$, on $\mathrm{M}-17$ agar on $30^{\circ} \mathrm{C}$ or $40^{\circ} \mathrm{C}$ and on SAB medium (Reference: Sengun et al. 2009)

\begin{tabular}{|c|c|c|c|c|c|c|c|c|c|c|}
\hline \multirow{2}{*}{$\begin{array}{l}\text { Tarhana samples } \\
\text { (Sampling region/site) } \\
\text { Sample G (Usak/City } \\
\text { Center) }\end{array}$} & \multirow{2}{*}{$\begin{array}{c}\begin{array}{c}\text { Fer- } \\
\text { men- } \\
\text { tation } \\
\text { time, d }\end{array} \\
21\end{array}$} & \multicolumn{8}{|c|}{ Sampling time, $d$} & \multirow{2}{*}{$\begin{array}{c}\begin{array}{c}\text { Dried } \\
\text { tarhana }\end{array} \\
\mathrm{T}\end{array}$} \\
\hline & & F0 & $\mathrm{F} 1$ & $\mathrm{~F} 2$ & F3 & F4 & F6 & F15 & $\mathrm{F} 21$ & \\
\hline LAB on MRS agar $30^{\circ} \mathrm{C}$ & & 7.5 & 7.4 & 6.8 & & 7.0 & 8.0 & & 7.7 & 3.1 \\
\hline LAB on M-17 agar $30^{\circ} \mathrm{C}$ & & 7.6 & 7.4 & 6.9 & & 6.9 & 8.0 & & 6.1 & 3.0 \\
\hline $\mathrm{SAB}$ & & 5.9 & 5.7 & 5.4 & & 5.3 & 7.0 & & 5.1 & 2.0 \\
\hline LAB on MRS agar $40^{\circ} \mathrm{C}$ & & 7.3 & 7.5 & 7.4 & & 7.4 & 8.0 & & 6.0 & 1.3 \\
\hline $\mathrm{LAB}$ on $\mathrm{M}-17$ agar $40^{\circ} \mathrm{C}$ & & 7.3 & 7.2 & 7.0 & & 6.8 & 7.5 & & 4.6 & 3.5 \\
\hline SAB & & 5.6 & 5.4 & 5.4 & & 5.5 & 6.0 & & 4.2 & 10 \\
\hline $\begin{array}{l}\text { Sample H } \\
\text { (Isparta/sarkikaraagac) }\end{array}$ & 3 & F0 & $\mathrm{F} 1$ & $\mathrm{~F} 2$ & F3 & $\mathrm{F} 4$ & F6 & F15 & F21 & $\mathrm{T}$ \\
\hline LAB on MRS agar $30^{\circ} \mathrm{C}$ & & 6.4 & 6.1 & 7.1 & 6.9 & & & & & 5.8 \\
\hline LAB on M-17 agar $30^{\circ} \mathrm{C}$ & & 6.6 & 6.4 & 7.1 & 7.0 & & & & & 6.2 \\
\hline SAB & & 2.3 & 1.7 & 1.6 & 1.8 & & & & & 2.8 \\
\hline LAB on MRS agar $40^{\circ} \mathrm{C}$ & & 6.4 & 6.5 & 6.8 & 6.9 & & & & & 4.8 \\
\hline LAB on M-17 agar $40^{\circ} \mathrm{C}$ & & 6.3 & 5.9 & 6.2 & 10.3 & & & & & 4.8 \\
\hline SAB & & 2.0 & 2.3 & 2.7 & 3.4 & & & & & 3.8 \\
\hline
\end{tabular}

\section{Conclusions}

A great variety of microorganisms was observed during the fermentation time of the two fermented milk/cereal products, the Greek/Cyprus Trahanas and the Turkish Tarhana. The microbiological properties of these fermented milk/cereal products change according to the raw materials, the fermentation time and the techniques used for their production. The lactic acid bacteria Streptococcus lactis, Streptococcus diacetylactis, Leuconostoc cremoris, Lactobacillus lactis, Lactobacillus casei, Lactobacillus bulgaricus and Lactobacillus acidophilus play the main role in lactic acid bacteria fermentation of Greek Trahanas. Lactococcus, Lactobacillus and yeast species contribute to a great extent to the completion of the fermentation process of Cyprus Trahanas. Lactobacillus spp. count in wet Turkish Tarhana was found to be higher than in the dried one. In Turkish Tarhana that was produced under controlled technological conditions, a higher presence of $P$. acidilactici than lactobacilli were found in Tarhana fermented at $40^{\circ} \mathrm{C}$, while the opposite happened in Tarhana fermented at $30^{\circ} \mathrm{C}$. The main lactic acid bacteria found were $L$. plantarum and L. brevis. In Turkish Tarhana, yeasts were mainly represented by $S$. cerevisiae. The addition of kefir in Turkish Tarhana production increased the count of lactic acid bacteria but insignificantly affected yeast and total mesophilic aerobic bacteria counts. Also, kefir was found to be another good alternative that can be used in Tarhana fermentation. In Turkish Tarhana formulated with different flours a significant effect of both flour type and fermentation time on yeasts and mesophilic lactic acid bacteria was observed. However, the thermophilic lactic acid bacteria were only affected by the fermentation time. Whole wheat flour Turkish Tarhana and chickpea flour Turkish Tarhana were found to be good alternatives to classical Turkish Tarhana. In Turkish Tarhana made with the addition of Tarhana herb (Echinophora sibthorpiana), the addition of Turkish Tarhana herb was found not to allow the decrease in the lactic acid bacteria population during the fermentation process as well as the yeast population at the first two days of fermentation. Various species of yeast and lactic acid bacteria were detected during natural Turkish Tarhana fermentation. Lactic acid bacteria were the predominant strains determined. E. durans, $L$. plantarum, S. cerevisiae, $K$. marxianus and $Y$. lipolytica were the main strains found at the end stages of Turkish Tarhana fermentation. The viability of the microbiota, especially lactic acid bacteria maintained during the storage period of wet Turkish Tarhana. 


\section{References}

Arslan-Tontul S., Multu C., Candal C., Erba M. Microbiological and chemical properties of wet tarhana produced by different dairy products. Journal of Food Science and Technology, 2018, 55(12): 1-7. https://doi.org/10.1007/s13197-0183410-9

Bozoudi D., Agathokleous M., Anastasiou I., PapademasPh., Tsaltas D., Microbiological Characteristics of Trachanas, a traditional fermented dairy product from Cyprus. Journal of Food Quality, 2017, Article ID 8749316.

https://doi.org/10.1155/2017/8749316

Dağlioğlu O. Tarhana as a traditional Turkish fermented cereal food. Its recipe, production and composition.

Die Nahrung, 2000, 44(2):85-88.

http://doi.org/10.1002/(SICI)15213803(20000301)44:2<85::AID-FOOD85>3.0.CO;2$\underline{\mathrm{H}}$

Degirmencioglu N., Gocmen D., Dagdelen A., Dagdelen F. Influence of Tarhana herb (Echinophora sibthorpiana) on fermentation of Tarhana, Turkish traditional fermented food. Food Technology Biotechnology, 2005, 43(2): 175-179. https://pdfs.semanticscholar.org/ea64/e6a03ec77bc3 77a6f2201dd77c47c46ca9d7.pdf

Demirci A., Palabiyik I., Ozalp S., Tirpanci Sivri G. Effect of using kefir in the formulation of traditional Tarhana. Food Science and Technology, Campinas. 2019, 39(2): 358-364. https://doi.org/10.1590/fst.29817

Economidou P., Steinkraus, K. Greek trahanas. In: Handbook of Indigenous Fermented Foods, Steinkraus Ed., Marcel Dekker Inc., New York, 1983, pp. 271-276.

Erbas M., Muharrem Certel M., Uslu M. K. Microbiological and chemical properties of Tarhana during fermentation and storage as wet-sensorial properties of Tarhana soup. LWT-Food Science and Technology, 2005, 38(4): 409-416. http://doi.org/10.1016/J.LWT.2004.06.009

Georgala A. The nutritional value of two fermented milk/cereal foods named 'Greek Trahanas' and 'TurkishTarhana': a review, 2013, Journal of Nutritional Disorders and Therapy, S(11): 1-4. http://doi.org/10.4172/2161-0509.S11-002

Hendek Ertop M., Gorkem Cerit Z., Atasoy R. Evaluation of physicochemical, nutritional and sensory properties of the wet Tarhana. Food Science and Quality Management, 2019, 83(1): 61-67. http://doi.org/10.7176/FSQM/83-08
Ibanoglu S., Ibanoglu E., Ainsworth P. Effect of different ingredients on the fermentation activity in Tarhana. Food Chemistry, 1999, 64(1):103-106. https://doi.org/10.1016/S0308-8146(98)00071-5

Kivanc M., Funda E. A functional food: a traditional Tarhana fermentation. Food Science Technology. Campinas, 2017, 37(2): 269-274. http://doi.org/10.1590/1678-457X.08815

Kumral A. Nutritional, chemical, microbiological changes during fermentation of Tarhana formulated with different flours. Chemistry Central Journal, 2015, 9(16):1-8. http://doi.org/10.1186/s13065-015-0093-4

Lazos E., Aggelousis G., Bratakos M. The fermentation of trahanas: a milk-wheat flour combination. Plant Foods and Human Nutrition, 1993, 44(7): 45-62. https://doi.org/10.1007/BF01088482

Ozdemir S., Gocmen D., Kumral A. A traditional Turkish fermented cereal food: Tarhana. Food Reviews International, 2007, 23 (2):107-121. https://doi.org/10.1080/87559120701224923

SengunI.Y., Dennis S. Nielsen D., Karapinar M., Mogens Jakobsen M. Identification of lactic acid bacteria isolated from Tarhana, a traditional Turkish fermented food. International Journal of Food Microbiology, 2009, 135(2): 105-111. https://doi.org/10.1016/j.ijfoodmicro.2009.07.033

Sengun, I., Karapinar M. Microbiological quality of Tarhana, Turkish cereal based fermented food. Quality Assurance and Safety Crops and Foods, 2012, 4(1): 17-25. https://doi.org/10.1111/j.1757-837X.2011.00118.x

Settanni L., Tanguler H., Moschetti G., Reale S., Gargano V., Erten H. Evolution of fermenting microbiota in tarhana produced under controlled technological conditions. Food Microbiology, 2011, 28(7): 1367-1373. https://doi.org/10.1016/j.fm.2011.06.008

Simsek O., Ozel S., Hilmi Con A. Comparison of lactic acid bacteria diversity during the fermentation of Tarhana produced at home and on a commercial scale. Food Science and Biotechnology, 2017, 26(1):181-187. https://doi.org/10.1007/s10068-017-0024-3

Tamime A., O'Connor T.. Kishk. A dried fermented milk/cereal mixture. International Dairy Journal, 1995, 5(2):109-128. https://doi.org/10.1016/0958-6946(95)92205-I 